\title{
The Impact of ROA, BOPO, FDR, CAR, NPF on Mudharabah Profit Sharing Rate
}

\author{
Bramandita $^{1}$ and Harun ${ }^{2}$ \\ ${ }^{1}$ Universitas Muhammadiyah Surakarta \\ ${ }^{2}$ Universitas Muhammadiyah Surakarta \\ email: bramamufc@yahoo.co.id,har179@ums.ac.id
}

\begin{abstract}
This research was conducted to analyze the effect of Return on Assets (ROA), Operational Cost of Operating Income (BOPO), Financing Deposit Ratio (FDR), Capital Adequacy Ratio (CAR), and Non-Performing Financing (NPF) on the level of profit-sharing at Mudharabah Banks Syariah with Case Study of BNI Syariah Bank in Indonesia. The data used is using the data recorded in the Financial Services Authority and financial reports published in 2016-2018. The data analysis method that will be used is Ordinary Least Square OLS after a series of Classical Assumptions tests. This research results that were partially finding the independent variables ROA, BOPO, FDR, and CAR have a significant effect. Meanwhile, the NPF variable does not have a significant effect on the Mudharabah Profit Sharing variable. This study shows that the NPF ratio is a picture of non-performing loans that do not significantly affect mudharabah profit-sharing, emphasizing the superiority of sharia contracts, especially mudharabah contracts.
\end{abstract}

Keywords: Return on Assets (ROA), Operational Costs Operating Income (BOPO), Financing Deposit Ratio (FDR), Capital Adequacy Ratio (CAR), and Non-Performing Financing (NPF), mudharabah profit-sharing financing.

\section{INTRODUCTION}

Banks can provide loans to people who need funds. The public can directly get a loan from the bank, as long as the borrower can meet the requirements provided by the bank. Banks have a role in two ways, namely collecting funds directly from people who 
are excess funds (surplus units), and channeling funds directly to people who need funds (deficit units) to meet their needs (Ismail, 2011). Banks in Indonesia are divided into two, namely conventional banks and Islamic banks. In each bank's system, conventional banks rely on the interest system, while Islamic banks that use Islamic sharia rely on the profit-sharing system that has been agreed by two parties.

Law No. 10 of 1998 and its implementing regulations are the development of bank business activities based on sharia principles. In-Law No. 10 of 1998, regulations on the implementation of financing based on the sharia system are further emphasized and expanded again in the legislation. The law also states that the position of Islamic banks in Indonesia is legally starting to become influential even in that it is written that conventional banks are allowed to open sharia-based units (Ismail, 2010).

Support for Sharia Banking is getting stronger with the passing of Law No. 21 of 2008 concerning Islamic Banking(Antonio, 2011). In October 2018, there were 13 BUS (Sharia Commercial Banks) and 25 UUS (Sharia Business Units) with an average total asset of Rp 454,249 billion in 2018 and successfully absorbed more than 56,691 workers. This data does not include data from the Islamic People's Financing Bank (BPRS). One of the significant supports from the Indonesian government is the implementation of office channeling policies. It also accelerated government support in the form of hajj account management that will be entrusted to Sharia Banking. The presence of new investors will encourage the growth of sharia business("Statistics on Sharia Development," 2018).

According to Mawardi (2008), in Novianti et al. (2015), factors that are considered by the public to invest their funds in Islamic banks are the profit-sharing return factor. That is, fund depositors will always consider the level of return earned in investing. If the level of profit-sharing of an Islamic bank is too low, customer satisfaction with the Islamic bank will decrease, and the customer will likely transfer the funds to another bank. Such customer characteristics make the profit-sharing level a 
determining factor for the success of Islamic banks in collecting Third Party Funds (DPK).

Based on the background and formulation of the problem, the purpose of this study was to determine the effect of the variable ROA, BOPO, FDR, CAR, NPF on mudharabah profit-sharing in BNI Syariah, 2016-2018 period. The results of this study are expected to be useful and broaden knowledge and references for academics and stakeholders in the Islamic economic environment.

\section{LITERATURE REVIEW Mudharabah Profit Sharing}

Profit-sharing is the profit or the results obtained from the management of funds, both investment and sale and purchase transactions provided by customers.

The principle of profit-sharing, according to Wiroso (2005), consists of (1) Determination of the magnitude of the risk of profit-sharing made at the time of the contract based on the possibility of profit and loss. (2) The size of the profit-sharing ratio is based on the amount of profit obtained. (3) The amount of profit-sharing distribution increases following the increase in the amount of revenue. (4) No one doubts the profit sharing. (5) Revenue sharing depends on the profit of the project being carried out. If the project does not benefit, the loss will be shared by both parties.

Profit-sharing is a critical characteristic for Islamic banks, so in their operational mechanism, Islamic banks use principles under Islamic law. The principle of profit-sharing is an instrument that distinguishes the operations of Islamic banks with conventional banks. So that the calculation is also far different from the calculation of interest used as a basis for conventional banks, based on the above understanding, it can be concluded that Islamic banking in its operations does not recognize the term usury (interest). Instead, it uses profit and loss sharing or better known as profit sharing(Yudiana, 2015).

The principle of profit-sharing in al-mudharabah differs from the principle of fixed interest. The bank will collect the recipient 
of financing (the customer) a fixed amount regardless of the profit generated by the customer.

There are two profit-sharing calculation systems in Islamic banking, namely:

1. Profit-Sharing is a calculation of profit-sharing, which is the net profit of the total revenue after deducting the costs incurred for that income. In Islamic banking, profit sharing is known as a profit and loss sharing, meaning that is where the division between profits and losses from operating income.

2. Revenue Sharing is the process of dividing revenue that is carried out before calculating operational costs borne by the bank. In another sense, revenue has a meaning, namely, the results of sales revenue made both from goods or services to produce sales revenue. In addition to profit-sharing from mudharabah deposits, there are several service products in Islamic banking, including the following:

Mudharabah profit sharing, according to Ismail (2011), is an investment fund that is placed by a customer that is not contrary to Islamic principles and can only be withdrawn at a particular time, under an agreement between the bank and the investor's customer.

A unique form of financial contract that has been developed to replace the interest mechanism in financial transactions is the profit-sharing mechanism. The profit-sharing mechanism is a core product for Islamic financial institutions, such as Islamic banks. Because Islamic banks explicitly prohibit the application of interest rates on all financial transactions(Muhammad, 2014).

According to Muhammad (2014), in general, the principle of Islamic banking profit sharing can be done in 4 (four) central contracts, but the most widely used in Islamic banking is Al-Musyarakah, Al-Mudharabah. Pillars in the Mudharabah transaction include (1) the existence of a capital owner (shahibul maal), (2) Mudharib (implementation or businessman, (3) Capital (maal), (4) Work or business, (5) Profit, and (6) Ijab Kabul. 


\section{Mudharabah Profit Sharing Financing}

Mudharabah is a cooperation agreement in which a person becomes a shahibul maal owner of capital or his wealth to the manager (mudharib) to be managed in the form of a business or business. In this context, the financial institution acts as shahibul maal (the owner of the funds) to finance $100 \%$ of the needs of a business project. In contrast, the entrepreneur who gets the funds, serves as the mudarib (fund manager). The business period, procedures for refunding, and sharing of profits are regulated by both parties.

In conducting business, financial institutions do not participate in business management. The financial institutions here are only business supervisors. The amount of funding must be precise (cash) and not receivable. Financial institutions here bear all the losses that occur when the business is carried out except when mudharib make a deliberate mistake, or not by the agreement. Mudharabah Profit Sharing Financing is financing provided by financial institutions to other parties for a productive business(Indonesian, nd).

The following are the characteristics of the provisions for financing profit-sharing mudharabah:

a. Mudharabah Profit Sharing Financing is intended for a halal productive enterprise.

b. Islamic financial institutions or Islamic banks only finance $100 \%$ of business needs, and customers act as mudarib.

c. During the period of the business, the procedures for controlling and sharing profits are determined at the time of the initial agreement.

d. Islamic financial institutions or Islamic banks do not participate in business management but have rights in business supervision and business coaching.

e. The agreed amount of funds must be definite and not in the form of receivables.

f. Islamic financial institutions or Islamic banks bear all losses except if mudharib commits intentional, negligent, and violates the agreement. 
g. In principle, mudharabah financing is no guarantee. So that mudarib does not make any deviations, the Islamic Financial Institution may ask for guarantees from mudarib or a third party. Guarantees can be disbursed if mudharib is proven to have violated the contract.

\section{The Effect of ROA on Mudharabah Profit-Sharing Rate}

According to Hanafi (2009), ROA is a profitability ratio. This ratio measures companies' ability to generate profits at a certain level of sales, assets, and share capital.

According to Khairiyah \& Sunaryo (2012), ROA is one of the profitability ratios used to measure the effectiveness of the company in generating profits and utilizing the total assets it has. The higher the value of ROA, the greater the company's performance because of the greater company return. Based on the understanding of the experts above, it can be concluded that ROA illustrates the ability of banks to manage funds invested and generate profits.

Novianti et al. (2015) found to yield positive and not significant ROA findings on the mudharabah profit-sharing rate. WhileHfiah et al. (2016)m Generating ROA has a positive and significant effect on the level of mudharabah profit sharing. Otherwise, Rahmawaty \& Tiffany (2015) produce findings that ROA has a negative and not significant effect on the level of mudharabah profit sharing.

\section{The Influence of Operational Income Operational Cost (BOPO) Ratio Against Mudharabah Profit-Sharing Rate}

According to Rahayu \& Bustamam (2016), BOPO is the ratio between operating costs and operating income. The operating cost ratio is used for the distribution of bank costs in carrying out its operations. Because the main activity of a bank is in principle acting as an intermediary that is raising funds and channeling funds, the lower the BOPO means, the more efficient the bank is in controlling its operational costs. With the existence of cost efficiency, the higher profits the bank will get. 
BOPO (Operating Expenses to Operating Income), a ratio often called the efficiency ratio, is used to measure the ability of bank management to control operational costs to operating income.

Based on the opinion of the experts above, it can be concluded that the BOPO is a ratio that shows the efficiency of the bank's operational performance. If the BOPO ratio is small, the bank's income will increase so that the profit-sharing that will be received by customers will increase as well, and vice versa.

Farianto (2014) produces findings that BOPO has a positive and not significant effect on mudharabah profit sharing. OtherwiseKhairiyah \& Sunaryo (2012); Rahayu \& Bustamam (2016) found that BOPO had a negative and insignificant effect on the level of mudharabah profit sharing.

\section{Effect of Financing To Deposits Ratio (FDR) Against the Rate of Profit-Sharing Mudharabah}

According to toSjahdeini (1999), Financing to Deposit Ratio (FDR) is a comparison between financing provided by banks with third-party funds that have been successfully mobilized by banks. FDR is a ratio that illustrates the ability of Islamic banks to return funds to third parties through profits derived from mudharabah financing(Setiawan, 2012).

Rahmawaty \& Tiffany (2015)making findings that FDR has a negative and not significant effect on the level of mudharabah profit sharing. On the other hand, other research shows that FDR has a positive and significant effect on mudharabah profit-sharing rates(Gundari, 2015; Harfiah et al., 2016).

\section{Effect of Capital Adequacy Ratio (CAR) on the Rate of Profit- Sharing Mudharabah}

According to Umiyati \& Syarif (2016), CAR is the ratio of bank performance to measure the capital adequacy of banks in maintaining capital and controlling the risks that arise that can affect the amount of capital because capital is an essential factor in a bank's business unit. The higher the CAR value (according 
to $\mathrm{BI}$ regulation $8 \%$ ), the better the financial performance, but if the CAR is lower than $8 \%$, the financial performance is reduced.

Based on the expert opinion above, it can be concluded that CAR is a capital ratio that illustrates banks' ability to control the likelihood of risks that occur so that their capital can be fulfilled. So, the higher the CAR ratio, the rate of bank profits will also increase, and the level of profit-sharing that will be given to customers will increase, and vice versa. Rahayu (2015) produces CAR findings that have a positive and not significant effect on the level of mudharabah profit sharing. Findings of positive effects are also found in Gundari (2015), but CAR is significant on the level of mudharabah profit sharing.

\section{The Effect of Non-Performing Financing (NPF) on the Rate of Profit-Sharing of Mudharabah}

NPF is the ratio between problem financing and the total financing channeled by Islamic banks.

NPF is the ratio between the amount of financing that is uncollected or classified as non-current with substandard, doubtful, and lousy quality(Arifa, 2008). If the NPF is high, the probability decreases, and the rate of profit sharing decreases. Conversely, if the NPF goes down, then the probability will rise, and the rate of profit sharing will also increase. The NPF standard is less than 5\%. Based on the opinion of experts, NPF can conclude that financing is terrible or problematic. The higher the NPF ratio, the bank's income will decrease so that the profit-sharing that will be given to customers will also decrease. Conversely, if the NPF ratio is low, then the bank's income will be high so that the profitsharing that will be given to customers will decrease. Novianti et al. (2015) indicate that NPF has a positive and not significant effect on the level of mudharabah profit sharing.

\section{Research Framework}

Based on the development of hypotheses, a research model can be built as follows: 


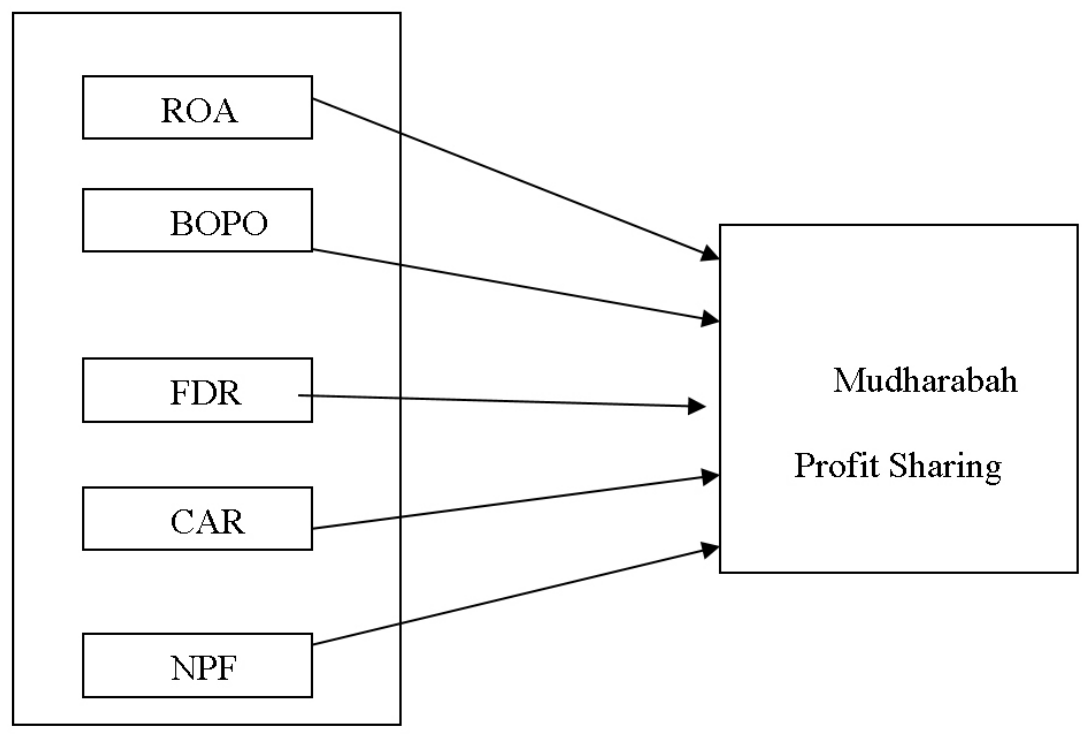

Figure 1. Research Framework

Source: (Iryana, 2017)

\section{Hypothesis}

The hypothesis is a temporary conjecture of a study. Based on the discussion of various theories and results of previous studies, hypotheses are formulated as follows:

Table 1: Previous Research Hypotheses

\begin{tabular}{cl}
\hline Hypothesis & \multicolumn{1}{c}{ Statement } \\
\hline H1 & $\begin{array}{l}\text { Return on assets (ROA) Has a Positive Effect on the Profit } \\
\text { Sharing Rate of Mudharabah Deposits. } \\
\text { H2 }\end{array}$ \\
BOPO Negative Influence Over Profit-Sharing Rate \\
Mudharabah Deposits. \\
FD & $\begin{array}{l}\text { Fasyarabah Deposit. } \\
\text { CAR Negatively Influences the Profit Sharing Rate of } \\
\text { Mudharabah Deposits. } \\
\text { H5 }\end{array}$ \\
& $\begin{array}{l}\text { NPF has a negative effect on the Profit Sharing Rate of } \\
\text { Mudharabah Deposits. }\end{array}$ \\
\hline
\end{tabular}




\section{METHODS}

\section{Object of Research}

This study uses a quantitative approach. The dependent variable in this study is ROA, BOPO, FDR, CAR, NPF. The independent variable is mudharabah profit-sharing financing. This study intends to analyze the effect of ROA, BOPO, FDR, CAR, NPF on the mudharabah profit sharing of the Syariah Commercial Bank Case Study at BNI Syariah from 2016 to 2018.

\section{Types and Data Sources}

The type of data used is secondary data in the form of time series data in January 2016 - December 2018. The data is obtained from the Monthly Publication Financial Statements website published by the Financial Services Authority on the official website www.ojk.go.id. The data used are mudharabah profit-sharing data and ROA, BOPO, FDR, CAR, NPF ratio data at Sharia Commercial Banks Case Study at BNI Syariah.

\section{Population and Samples}

The population in this study is the publication of mudharabah profit-sharing financing statistical data on Islamic Commercial Banks with the sample used is the publication of monthly Islamic Commercial Statistics. Data from January 2016 to December 2018 so that 36 months of monthly data have been obtained.

\section{Definition of Variable Operations}

Operational Variables are aspects of research that provide information to us about how to measure variables. Operational definitions are scientific information that significantly helps other researchers who want to conduct research using the same variables.

1. Dependent Variable

The dependent variable used in this study is mudharabah profit sharing

2. Independent Variables

The independent variables used in this study are:

a) Return on assets (ROA) 
b) Operating Costs Against Operating Income (BOPO)

c) Financing to Deposit Ratio (FDR)

d) Capital Adequacy Ratio (CAR)

e) Non-Performing Financing (NPF)

\section{Analysis Tools and Methods}

Analysis of the data in this study is a quantitative analysis expressed by the numbers by processing time-series data through the E-views program. The data analysis method used to determine the effect of the variables that affect mudharabah profit-sharing financing at Islamic Banks is used multiple regression with the Partial Adjustment Model (PAM), where the mudharabah profitsharing variable is the dependent variable. The variables ROA, BOPO, FDR, CAR, NPF, are influencing variables (independent variables).

The author modifies the model from Iryana, Sofiyani. ROA, BOPO, FDR, CAR, NPF Against Sharia Mudharabah Profit Sharing for Case Studies at BNI Syariah. Using the Ordinary Least Square (OLS) multiple regression analysis tool, the estimation equation is as follows:

$$
\mathrm{Y}=\mathrm{a}+\mathrm{b} 1 \mathrm{x} 1+\mathrm{b} 2 \times 2+\mathrm{b} 3 \times 3+\mathrm{b} 4 \mathrm{x} 4+\mathrm{b} 5 \times 5+\mathrm{e}
$$

Where :

$\mathrm{Y}=$ Mudharabah Profit Sharing

a $=$ constant

$\mathrm{b}=$ regression coefficient

$\mathrm{X} 1=R O A$

$\mathrm{X} 2=B O P O$

$\mathrm{X} 3=F D R$

$\mathrm{X} 4=C A R$

$\mathrm{X} 5=N P F$

Then the authors change the model, namely the Partial Adjustment Model (PAM) approach, the formulation of the estimator model is as follows: 


$$
\begin{gathered}
B H M t=\alpha 0+\alpha 1 R O A t+\alpha 2 B O P O t+\alpha 3 F D R t+\alpha 4 C A R t+ \\
\alpha 5 N P F t+t
\end{gathered}
$$

Where :

ROEt = Mudharabah Profit Sharing (Millions of Rupiah)

ROAt = Return on assets $(\%)$

BOPOt $=$ Operational Costs Operating Income (\%)

FDRt $=$ Financing Deposit Ratio $(\%)$

CARt $\quad=$ Capital Adequacy Ratio $(\%)$

$\mathrm{NPFt}=$ Non-Performing Financing $(\%)$

$$
=\text { year }
$$

Before applying regression, it must be tested by the parameter estimator model and classic assumption tests.

\section{RESULTS AND DISCUSSION \\ Estimated Results}

In this study, as stated that, to determine the effect of ROA (Return on Assets), BOPO, FDR (Financing Debt Ratio), CAR, and NPF on Mudharabah profit sharing for the period January 2016 - December 2018, ordinary least square regression analysis ( OLS) with the econometric model as follows:

$$
\mathrm{Y}=\mathrm{a}+\mathrm{b} 1 \times 1+\mathrm{b} 2 \times 2+\mathrm{b} 3 \times 3 \mathrm{~b} 4 \times 4+\mathrm{b} 5 \times 5+\mathrm{e}
$$

Where:

$$
\begin{aligned}
\mathrm{Y} & =\text { Mudharabah Profit Sharing } \\
\mathrm{a} & =\text { constant } \\
\mathrm{b} & =\text { regression coefficient } \\
\mathrm{X} 1 & =R O A \\
\mathrm{X} 2 & =B O P O \\
\mathrm{X} 3 & =F D R \\
\mathrm{X} 4 & =C A R \\
\mathrm{X} 5 & =N P F \\
\mathrm{E} & =\text { year }
\end{aligned}
$$


Table 2. Model Estimation Results Foreign Reserves in Indonesia 1999-2018

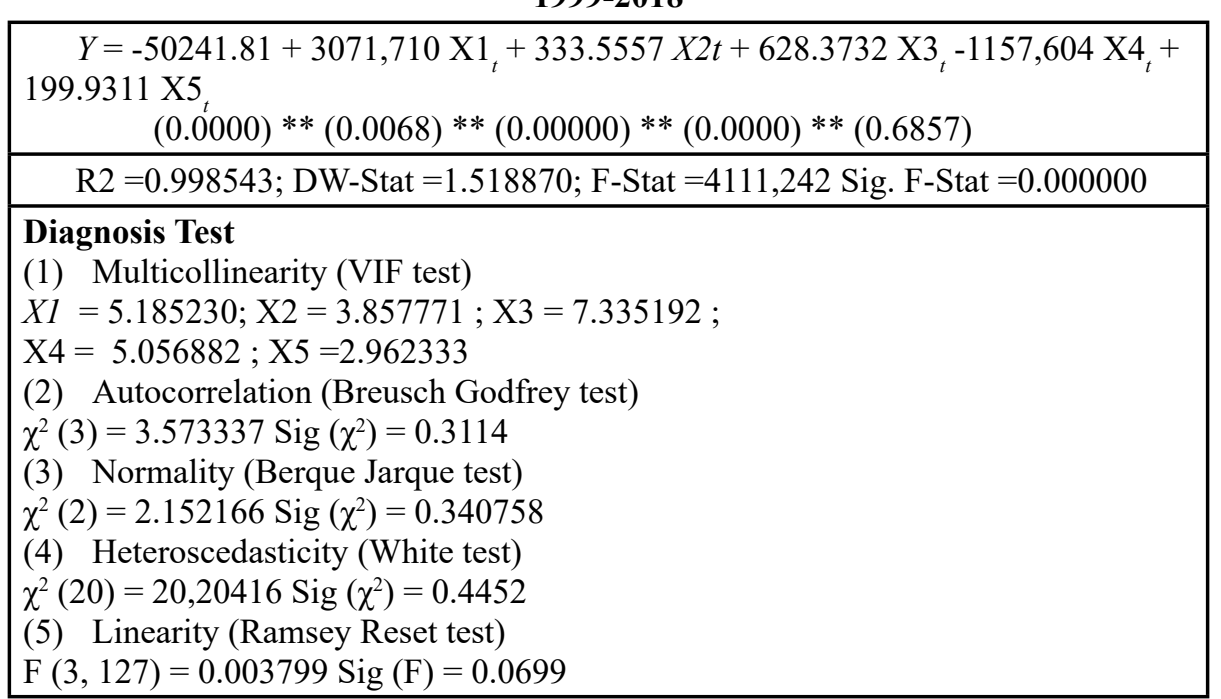

Source: $\{$ BPS, processed $\}$ Note: * Significant at $\alpha=0.01 ; * *$ Significant to $\alpha=0.05 ; * * *$ Significant to $\alpha=0.10$; Numbers in parentheses are empirical probabilities ( $p$ values) t-statistics.

\section{Classic assumption test Multicollinearity Test}

The multicollinearity test used in this study is the VIF test. If $\mathrm{VIF}>10$ then there is a problem in the variable, conversely if VIF $<10$ then there is no multicollinearity problem

Table 3. Multicollinearity Test Results

\begin{tabular}{cccc}
\hline Variable & VIF & Criteria & Conclusion \\
\hline ROA (X1) & 5.185230 & $<10$ & No multicollinearity problems. \\
BOPO (X2) & 3.857771 & $<10$ & No multicollinearity problems. \\
FDR (X3) & 7.335192 & $<10$ & No multicollinearity problems. \\
CAR (X4) & 5.056882 & $<10$ & No multicollinearity problems. \\
NPF (X5) & 2.962333 & $<10$ & No multicollinearity problems \\
\hline
\end{tabular}




\section{Residual Normality Test}

The Residual Normality Test in this study uses the Jarque Bera (JB) test. If Ho is accepted if the value of $p$ ( $p$-value), probability, or empirical statistical significance is $\mathrm{JB}>0.05$, then the data is concluded to be normally distributed. In contrast, if $\mathrm{JB}<0.05$, Ho is rejected, the data concluded are not normally distributed.

From Table 2, it can be seen that the JB statistic is 0.340758 $(>0.05)$, so Ho is accepted, which can be concluded that the data is typically distributed.

\section{Heteroscedasticity Test}

Heterokedastisitas test in this study uses the White test, where Ho is accepted if the probability or empirical significance of Chi. Square statistics $>0.05$, then the data concluded there is a heteroscedasticity problem; conversely, if Chi. Square $<0.05$ then Ho is rejected, the data concluded there is no heteroscedasticity problem

In Table 4.1, the Chi. Square white test probability is 0.4452 $(>0.05)$, so Ho is accepted so that it can be concluded in the data there is no heteroscedasticity problem.

\section{Autocorrelation Test}

The existence test for autocorrelation, which will be discussed here, is the Breusch-Godfrey test. If $\mathrm{HO}$ is accepted, there is no autocorrelation problem in the model. Ho was denied there was an autocorrelation problem in the model. $\mathrm{H} 0$ is accepted if $\chi^{2}$ arithmetic or statistics $\chi^{2} \leq \chi^{2}(\alpha, p)$, H0 is rejected if $\chi^{2}$ arithmetic or statistics $\chi^{2}>\chi^{2}(\alpha, p)$.

It can be seen in Table 2, the Chi. Square white test probability is $0.3114(>0.05)$, so Ho was accepted. It can be concluded that in the data, there is no autocorrelation problem.

\section{Linearity Test}

Model specification test or Linearity Test, in this study, using the Ramsey Reset test. H0: linear model (correct 
model specification), Ho: non-linear model (incorrect model specification). $\mathrm{H} 0$ is accepted if $\mathrm{F}$ arithmetic or statistics $\mathrm{F} \leq \mathrm{F}$ $(\alpha, p, N k), H 0$ is rejected if $\mathrm{F}$ arithmetic or statistics $\mathrm{F}>\mathrm{F}(\alpha, \mathrm{p}$, $\mathrm{Nk}$ ). In table 2, it can be seen that the value of empirical statistical significance of the Ramsey Reset F Test is equal to 0.0699 ( $>$ 0.05). Ho is accepted; it can be concluded that the model used is linear (valid model specifications).

\section{Model Goodness Test Model Existence (F Test)}

The existence test of the model uses the F test, wherein $\mathrm{H} 0$ : $\beta 1=\beta 2 \ldots=\beta 5=0$, the model used does not exist and HA: $\beta 1$ $\neq 0|\beta 2 \neq 0| \ldots \mid \beta 5 \neq 0$, the model used exists. H0 is accepted if the statistical significance of $\mathrm{F}>\alpha$ and $\mathrm{H} 0$ is rejected if the $\mathrm{F} \leq$ $\alpha$. This $F$ test uses probability (F statistic) compared to $\alpha$. If $\alpha>$ probability (F Statistic), then all independent variables influence the dependent variable.

From Table 2, it can be seen the p-value, probability, or empirical statistical significance $\mathrm{F}$ of $0.0000(<0.10)$; so Ho is rejected, the conclusion of the model used exists, and overall / simultaneous independent variables affect the dependent variable.

\section{Coefficient of Determination (R2)}

The coefficient of determination (R2) shows the predictability of the estimated model. From Table 2, you can see the value (R2) of 0.998543 . Thus, $99.8 \%$ of the variation of the mudharabah profit-sharing variable can be explained by variations in the ROA, BOPO, FDR, CAR, and NPF variables. In comparison, the remaining $0.2 \%$ is influenced by variations of variables or other factors outside the model.

\section{Validity Test of Effect of Independent Variables}

The validity test of the effect used in this study is the t-test, $\mathrm{HO}:=0$; independent variable $\mathrm{I}$ dependent variable that is Mudharabah Profit Sharing with the dependent variable. HA: $\neq 0$; independent variable, It has a significant effect on the dependent 
variable. $\mathrm{H} 0$ is rejected if the statistical significance $\leq \alpha=0.05$ and $\mathrm{H} 0$ is accepted if the statistical significance $>\alpha=0.0$. T-Test results can be seen in Table 4 .

Table 4. Effect Validity Test Results

\begin{tabular}{cccc}
\hline Variabel & sig. t & Criteria & Conclusion \\
\hline ROA (X1) & 0.0000 & $<0.05$ & significant at $\alpha=0.01$ \\
BOPO (X2) & 0.0068 & $<0.05$ & significant at $\alpha=0.01$ \\
FDR (X3) & 0.0000 & $<0.05$ & significant at $\alpha=0.01$ \\
CAR (X4) & 0.0000 & $<0.05$ & significant at $\alpha=0.01$ \\
NPF (X5) & 0.6857 & $>0.05$ & Not significant \\
\hline
\end{tabular}

Source: Data processed

\section{Interpretation Influence Independent Variable}

Based on the results of the validity test, the influence of table 4.3 shows that all independent variables, namely the variable ROA, BOPO, FDR, and CAR, have a significant influence on the dependent variable that is the mudharabah profit sharing. While the NPF variable has a positive but not significant effect on mudharabah profit sharing. The following are interpretations of the effect of significant independent variables on the dependent variable in the study:

The ROA variable has a regression coefficient of 3071,710 . The pattern of the relationship between mudharabah profit-sharing variables and ROA variables is linear-logarithmic, meaning that if mudharabah profit-sharing increases by one percent, ROA profitability will increase by $3071,710 / 100=30.72 \%$. Conversely, if ROA drops $1 \%$, mudharabah profit sharing will decrease by $30.72 \%$.

The BOPO variable has a regression coefficient of 333,5557. The pattern of the mudharabah profit-sharing variable relationship with the BOPO variable is linear-logarithmic. This result means that if the mudharabah profit share increases by one percent, the BOPO will increase by333,5557/ $100=33.34 \%$. Conversely, if the BOPO drops by $1 \%$, the mudharabah profit sharing will decrease by $33.34 \%$. 
The FDR variable has a regression coefficient of 628,3732 . The relationship pattern of $\mathrm{n}$ variables for mudharabah profit sharing with FDR variables is linear-logarithmic, meaning that if mudharabah profit sharing increases by one percent, then FDR profitability will increase by $628,3732 . / 100=6.28 \%$. Conversely, if FDR goes down $1 \%$, mudharabah profit sharing will decrease by $6.28 \%$.

CAR variable has a regression coefficient of $-1157,604$. The pattern of the relationship between mudharabah profit-sharing variables and CAR variables is linear-logarithmic, meaning that if mudharabah profit sharing increases by one percent, CAR profitability will decrease by-1157,604/ $100=11.58 \%$.

\section{Interpretation The economy}

Based on the results of the study above, it states that mudharabah profit sharing is influenced by several variables, including ROA, BOPO, FDR, CAR, and NPF variables. To find out the economic interpretation and influence of each variable will be explained as follows:

\section{Effect of ROA (X1) on Mudharabah Profit Sharing}

Based on the research results, ROA or population has a positive and significant effect on Mudharabah Profit Sharing. According to Harfiah et al. (2016), ROA has a positive and significant effect on the profit-sharing rate for mudharabah deposits.

According to Khairiyah \& Sunaryo (2012b) (ROA is one of the profitability ratios used to measure the company's effectiveness in generating profits and utilizing its total assets. The greater the value of ROA, the greater the company's performance because of the greater corporate returns. Based on the above understanding, experts can be drawn ROA conclusions illustrate the ability of banks to manage funds invested and generate profits.

The ROA situation in this study shows that the data obtained on average per year of profitability or financial gain from Islamic banking is $1.22 \%$. In 2016 amounted to $1.18 \%$, in 2017 amounted to 0.96 and in 2018 amounted to $1.52 \%$. Although the benefits 
obtained are not so maximal, at least every year, the profits of Islamic banks experience positive fluctuations.

\section{Effect of BOPO (X2) on Mudharabah Profit Sharing}

Based on the results of research that has been done, BOPO has a positive and significant effect on Mudharabah Profit Sharing. This finding is in accordance with research(Iryana, 2017)concerning the analysis of the effect of ROA, BOPO, FDR, CAR, and NPF on the Profit Sharing Rate of Mudharabah Deposits. Thesis. Faculty of Islamic Economics and Business, IAIN Salatiga. The results of his research explained that partially BOPO had a positive and significant effect.

According to Rahayu \& Bustamam (2016), BOPO is the ratio between operating costs and operating income. The operating cost ratio is used for the distribution of bank costs in carrying out its operations. Because the main activity of a bank is in principle acting as an intermediary the lower, the BOPO means the more efficient the bank is in controlling its operational costs, with the existence of cost efficiency, the greater profits the bank will get.

BOPO (Operating Expenses to Operating Income), a ratio that is often called the efficiency ratio, is used to measure the ability of bank management in controlling operational costs to operating income.

This means that BOPO has an effect on profit-sharing in the mudharabah contract. For three years in the BOPO research, it has continued to decline, meaning that bank management in controlling operational costs towards operating income is running well. Profit-sharing obtained by Islamic banking depends on the size of the BOPO.

\section{Effect of FDR (X3) on Mudharabah Profit Sharing}

Based on the results of research that has been done, FDR has a positive and significant effect on Mudharabah Profit Sharing. This is in accordance with research Harfiah et al. (2016), which shows the FDR has a positive and significant effect on the profitsharing rate of mudharabah deposits.

FDR is a comparison between financing provided by banks 
with third-party funds that have been successfully mobilized by banks (Rahmawaty \& Tiffany, 2015).

According to Setiawan (2012) is a ratio that illustrates the level of ability of Islamic banks in returning funds to third parties through profits derived from mudharabah financing. Comparison between financing and third-party funds, in this case, the customer or investor. FDR in this study is said to be positive and significant for mudharabah profit-sharing in Islamic banks, meaning that financing provided by banks with third-party funds has been successfully mobilized by banks. Profit-sharing using the mudharabah contract at FDR provides a return of profits for Islamic banks.

\section{Effect of CAR (X4) on Mudharabah Profit Sharing}

Based on the results of research that have been done, CARnegative, and significant effect on Mudharabah Profit Sharing. This is following the research that CAR has a negative but significant effect.

According to Umiyati \& Syarif (2016), CAR is the ratio of bank performance to measure the capital adequacy of banks in maintaining capital and controlling the risks that arise that can affect the amount of capital because capital is one crucial factor in a bank's business unit. The higher the CAR value (according to $\mathrm{BI}$ regulation $8 \%$ ), the better the financial performance, but if the CAR is lower than $8 \%$, the financial performance is poor.

Based on the economic conditions in Islamic banking in 2016 - 2018, the condition of the high CAR ratio and the level of bank profit will also increase, and the level of profit-sharing that will be given to customers will increase, and vice versa.

\section{Effect of NPF (X5) on Mudharabah Profit Sharing}

Based on the results of research that has been done, NPF has no significant effect on mudharabah profit sharing. This is following research Novianti et al. (2015), which shows the NPF has no significant effect on the level of profit-sharing mudharabah.

NPF is the ratio between problem financing and the total financing channeled by Islamic banks. Based on the NPF 
conditions for mudharabah profit-sharing in sharia banking in 2016 - 2018, the bad credit in this research is a case study at BNI Syariah Bank in Indonesia. This can be seen in the data that NPF within 36 months is not so large, an average of $4.75 \%$ in the medium category, so that in BNI Syariah NPF does not affect mudharabah profit sharing.

\section{CONCLUSION}

Based on the research and estimation results of the regression that has been done, this research shows partially the independent variables ROA, BOPO, FDR, and CAR have a significant effect. Besides, the NPF variable does not have a significant effect on the Mudharabah Profit Sharing variable. Further research is expected to modify the independent variables by adding variables or adding time series data. So it will be more objective and varied in conducting research. This study shows that the NPF ratio that is a picture of non-performing loans does not significantly affect mudharabah profit-sharing, emphasizing the superiority of sharia contracts, especially mudharabah contracts.

\section{REFERENCES}

Antonio, M. S. (2011). Bank Syariah dari Teori ke Praktek. Depok: Gema Insani.

Arifa, U. (2008). Analisis Pengaruh Non Performing Financing(NPF) dan Financing To Deposits Ratio(FDR) terhadap persentase return bagi hasil deposito mudharabah mutlaqah pada Bank Muamalat Indonesia. UIN Syarif Hidayatullah Jakarta.

Farianto, A. (2014). Analisis pengaruh Return On Asset(ROA), BOPO dan BI-Rate Terhadap Tingkat Bagi Hasil Mudharabah pada Bank Umum Syariah di Indonesia Tahun 2012-2013. 2.

Gundari. (2015). Pengaruh Tenaga Kinerja Keuangan Terhadap Tingkat Bagi Hasil Mudharabah pada Bank Mega Syariah Indonesia Tahun 2004-2013. Jurnal Profita, 3.

Hanafi. (2009). Analisis Laporan Keuangan. Yogyakarta. 
Harfiah, L. M., Purwati, A. S., \& Ulfah, P. (2016). The Impact Of ROA, BOPO, and FDR to Indonesian Islamic Banks Mudharabah Deposit Profit Sharing. Jurnal Ekonomic, 15.

Indonesia, M. U. Fatwa Dewan Syariah Nasional.

Iryana, S. (2017). Analisis Pengaruh ROA, BOPO, FDR, CAR, dan NPF terhadap bagi hasil Mudharabah pada Bank Umum Syariah Indonesia 2012-2018. Institut Agama Islam Negeri Salatiga.

Ismail. (2010). Manajemen Perbankan (Edisi Pert). Jakarta: Kencana.

Ismail. (2011). Manajemen Perbankan (Cetakan Ke). Jakarta: Kencana.

Khairiyah, A. I., \& Sunaryo, K. (2012a). Analisis Pengaruh Return On Asset (ROA), BOPO, dan Suku Bunga Terhadap Tingkat Bagi Hasil Mudharabah pada Bank Umum Syariah. Jurnal Ekonomi Dan Bisinis, 11.

Khairiyah, A. I., \& Sunaryo, K. (2012b). Analisis Pengaruh Return On Asset (ROA), BOPO, dan Suku Bunga Terhadap Tingkat Bagi Hasil Deposito Mudharabah. Jurnal Ekonomi Dan Bisnis, 11.

Muhammad, S. (2014). Lembaga Keuangan dan Ekonomi Islam. Yogyakarta: Ombak.

Novianti, N., Badina, T., \& Erlangga, A. (2015). Analisis Pengaruh Return On Asset (ROA), Biaya Operasional terhadap Pendapatan Operasional(BOPO), Suku bunga, Financing To Deposits Ratio(FDR), dan Non Performing Financing(NPF) Terhadap Tingakat Bagi Hasil Mudharabah (Studi Empiris pada Bank Umum Syariah.

Rahayu, P. A., \& Bustamam. (2016). Pengaruh Return On Asset(ROA), BOPO, dan Suku Bunga Terhadap Tingkat Bagi Hasil Mudharabah Pada Bank Umum Syariah. Ilmiah Mahasiswa Ekonomi Akuntansi(JIMEKA).

Rahayu, S. (2015). Pengaruh Return On Asset, BOPO, Suku Bunga, dan Capital Adequacy Ratio(CAR) Berpengaruh 
Positif dan Tidak Signifikan Terhadap Tingkat Bagi Hasil Mudharabah. Jurnal Ilmiah Mahasiswa S1 Akuntansi Universitas Pandanaran, 1(2502-7697).

Rahmawaty, \& Tiffany. (2015). Pengaruh Return On Asset(ROA) dan Financing To Deposits Ratio Terhadap Tingkat Bagi Hasil Mudharabah pada Bank Umum Syariah. Jurnal Dinamika Akuntansi Dan Bisnis, 2.

Setiawan, A. (2012). Analisis Pengaruh Kinerja Keuangan dalam Memprediksi Pertumbuhan Laba. 10.

Sjahdeini, S. R. (1999). Perbankan Islam. Jakarta: PT Pustaka Utama Grafiti.

Statistik Perkembangan Syariah. (2018).

Umiyati, \& Syarif. (2016). Pengaruh Prinsip Bagi Hasil dan Kualitas Pelayanan Terhadap Keputusan Anggota Menggunakan Produk Tabungan Mudharabah.

Yudiana. (2015). Analisis Perbandingan Kinerja Keuangan Bank Konvensional Dan Bank Syariah. JEAM, 14. 